\title{
PENDEKATAN PSIKOLOGI AGAMA DALAM PEMBELAJARAN AKIDAH AKHLAK DI MA AL-MUKHLISIN KAMPAO BLEGA BANGKALAN
}

\author{
Hayyul Mubarok \\ STAI AL-HAMIDIYAH BANGKALAN \\ E-Mail: hayyul_mubarok@yahoo.com
}

\begin{tabular}{|c|c|c|}
\hline Received & Revised & Accepted \\
\hline 4 July 2019 & 2 Agustus 2019 & 20 Agustus 2019 \\
\hline
\end{tabular}

\section{THE APPROACH OF THE RELIGION PSYCHOLOGY IN LEARNING AKIDAH AKHLAK IN MA AL-MUKHLISIN KEMPAO BLEGA BANGKALAN}

\begin{abstract}
The level of effectiveness of learning in MA AL-Mukhlisin Kampao, Blega District, Bangkalan District is strongly influenced by the behavior of educators and the behavior of students. Effective teaching behaviors include teaching clearly, using a variety of learning methods, using a variety of media or educational aids, enthusiasm, empowering students, and using contextual learning. Whereas student behavior can be viewed in terms of psychology. In the context, it relates to the scope of the learning approach used by the Akidah Akhlak teacher at MA Al-Mukhlisin, using the Psychology of Religion approach. His dentism, the approach of the psychology of religion can be defined as the study of human behavior or the study of the symptoms of the human soul associated with religion as a form of belief. Context as a reference to discuss these problems, using descriptive qualitative methods which are methods of analyzing the data obtained. The results of research conducted by researchers regarding the approach of the Psychology of Religion in the study of the Akidah Akhlak in MA Al-Mukhlisin, the researchers draw the following conclusions. In shaping the character of students in the learning process in terms of psychology by the teacher of the Akidah akhlak, traced the existence of inner pressures that befall on students who are very influential on achieving a goal of learning. Supporting Factors for the Implementation of the Psychological Approach Religion in Learning include; facilities and infrastructure, school culture, parental support, and individual differences.
\end{abstract}

Keywords: Religious Psychology, Akidah Akhlak, Education 


\begin{abstract}
Abstrak
Tingkat efektivitas pembelajaran di MA AL-Mukhlisin Kampao, Kecamatan Blega, Kabupaten Bangkalan sebagian dipengaruhi kepribadian pendidik dan juga kepribadian peserta didik. Hal tersebut tidak lepas dari peran atas perilaku, sebab satu sama lain harus saling mendukung. Pada konteksnya, pendidik yang mempunyai perilaku yang efektif mempunyai konsep mengajar yang jelas, memakai metode dan media pembelajaran yang bervariasi, dan memakai pembelajaran yang kontekstual. Sedangkan perilaku peserta didik dapat ditinjau dari segi sikologinya dengan mengikuti aturan-aturan yang diberikan oleh guru. Berkaitan dengan ruang lingkup pendekatan pembelajaran yang digunakan oleh guru Akidah Akhlak di MA Al- Mukhlisin, menggunakan pendekatan Psikologi Agama. Dentensinya, pendekatan psikologi agama bagian dari ilmu yang mempelajari tingkah laku manusia dan gejala-gejala jiwa manusia berkaitan dengan agama sebagai bentuk keyakinan. Konteks sebagai acuan untuk membahas permasalahan tersebut, menggunkan metode deskriptif kualitatif yang merupakan metode penganalisisan atas semua data yang diperoleh. Adanya hasil penelitian mengenai pendekatan Psikologi Agama dalam pembelajaran Akidah Akhlak di MA Al-Mukhlisin, maka peneliti mengambil kesimpulan sebagai berikut. Dalam pembentukan karakter siswa pada proses pembelajaran yang ditinjau dari psikologinya oleh guru Akidah Akhlak, ditelusuri adanya tekanan-tekanan batin yang menimpa pada diri siswa yang sangat berpengaruh atas tercapainya sebuah tujuan dari pembelajaran. Faktor Pendukung Pelaksanaan Pendekatan Psikologi Agama Pada Pembelajaran tersebut di antaranya; sarana dan prasarana, budaya sekolah, dan semangat siswa. Sedangkan faktor penghambat dalam proses pembelajaran ini yaitu, kurangnya dukungan orang tua dan perbedaan individu.
\end{abstract}

\title{
Kata Kunci: Psikologi Agama, Akidah Akhlak, Pendidikan
}

\section{Pendahuluan}

Pelaksanaan proses pembelajaran di sekolah, sebagian guru kadang kurang memahami dan memperhatikan pentingnya suatu bahan ajar dan tinjauan dari psikisnya. Dalam menyampaikan materi pelajaran yang tidak terstruktur, otomatis guru kurang memperhatikan adanya perkembangan murid dalam proses pembelajaran. Hal sedemikian juga pada murid, akan kurang maksimal dalam pencariannya terhadap ilmu, sehingga tidak dapat meningkatkan kualitas belajar dengan baik dan suatu keinginan pembelajaran yang efektif. Di sisi lain, tidak dapat berpikir dan bertindak secara sistematis dalam proses pelaksanakan pembelajaran, sedangkan untuk mencapai hal tersebut harus bertindak integratif, holistik, dan terpadu dalam mencapainya.

Sekolah merupakan bagian sitem dari konteks, imput, proses, output, dan outcome. Komponen tersebut saling berkesinambungan seperti halnya konteks berpengaruh pada input, input berpengaruh pada proses, proses berpengaruh pada output, serta output berpengaruh pada outcome. Sebuah sistem, terbentuk sub-sub sistem yang secara sinergis saling mendukung dalam mencapai tujuan penyelenggaraan program pendidikan. Aktivitas proses pembelajaran merupakan bagian penting karena dengan adanya pembelajaran tersebut akan terjadi interaksi antara pendidik dan peserta didik. Pembelajaran ini berlangsung dengan adanya peran pendidik ke-peserta didik sehingga bisa dipastikan hasil pendidikan 
bergantung pada perilaku keduanya. Atas hal tersebut, diyakini bahwa perubahan persepsi pembelajaran akan terjadi jika ada perubahan atara pendidik dan peserta didik, sehingga posisi pendidik dan peserta didik memiliki posisi penting untuk meningkatkan kualitas pembelajaran. ${ }^{1}$

Persiapan pembelajaran merupakan bagian yang meliputi standar kompetensi dan kompetisi dasar, metode, alat evaluasi, bahan ajar, media, fasilitas, waktu, tempat, dan harapan-harapan, serta perangkat informasi yang diperlukaan untuk menunjang adanya pelaksanaan proses belajar mengaajar. Kesiapan siswa berkaitan dengan fisik maupun mental, juga diperlukan hal-hal pendukung yang sangat penting seperti apa yang sudah disebutkan. Oleh sebabnya esensi persiapan proses pembelajaran adalah kegiatan segala hal yang dibutuhkan atas berlangsungnya proses belajar mengajar. Proses belajar mengajar merupakan peristiwa interaksi pendidik dan peserta didik yang diharap menghasilkan perubahan peserta didik dari belum mampu menjadi mampu dan yang belum terdidik menjadi terdidik ${ }^{2}$

Hakikat dari pentingnya proses belajar mengajar adalah efektivitasnya. Tingkat efektivitas tersebut sangat dipengaruhi perilaku pendidik dan peserta didik. Adapun perilaku pendidik yang efektif meliputi; mengajarnya jelas, menggunakan metode berbeda-beda dan lain sebagainya ${ }^{3}$. Namun yang terpenting pula menekankan pada keseriusan, kerajinan, kedisiplinan, sehat tanpa ada tekanan batin, dan mempunyai akhlak yang baik. Pembelajaran seperti ini agar efektif bisa melakukan suatu pendekatan psikologi agama yang meninjau anak didik dari segi dalam. Untuk mencapai efektivitas tinggi dari pendidik dan peserta didik, dibutuhkan adanya strategi proses pembelajaran kontekstual psikologi agama dengan mendekatkan realitas yang mengacu pada rendahnya tekanan dan tingginya pengalaman.

Eksistensi realitas bisa asli juga bisa tiruan, sedangkan jenis pengalaman bisa konkret dan abstrak. Oleh karenanya, diperlukan kinerja guru yang mendukung pencapaian kualitas tersebut melalui pendekatan-pendekatan yang ada. Seperti halnya pendekatan Psikologi Agama yang diterapkan oleh guru Akidah Akhlak di MA Al-Mukhlisin Kampao untuk mencapai suatu tujuan seorang guru terhadap muridnya dalam membentuk sikap dan tingkah laku, serta suasana keadaan proses pada umumnya. Pun dalam mempelajari pertumbuhan dan perkembangan jiwa agama pada peserta didik dan faktor-faktor yang mempengaruhi keyakinannya. Pada ruang yang lain, juga mengembangkan pemahaman atas perilaku keagaman dengan cara mengaplikasikan prinsip-prinsip psikologi yang diambil dari kajian perilaku tentang beragama terhadap seseorang dan beberapa besar pengaruh keyakinan agama itu terdapat dalam sikap dan tingkah laku serta keadaan yang ada. Dalam

\footnotetext{
${ }^{1}$ Slamet Suyanto, “Dasar-Dasar Pendidikan Anak Usia Dini,” Yogyakarta: Hikayat Publishing, 2005.

${ }^{2}$ Suyanto.

${ }^{3}$ Ali Miftakhu Rosyad, "THE ACTUALIZATION OF MULTICULTULARISM VALUES THROUGH SOCIAL STUDIES LEARNING AT STATE JUNIOR HIGH SCHOOL 2 JUNTINYUAT IN REGENCY INDRAMAYU BACKGROUND OF THE PROBLEM," n.d.
} 
konteks lain juga mempelajari pertumbuhan, perkembangan jiwa agama, dan faktor yang mempengaruhi keyakinannya. ${ }^{4}$

Adapun hal yang berkaitan dengan ruang lingkup pendekatan psikologi agama yang diterapkan oleh guru Akidah Akhlak di MA Al-Mukhlisin Kampao terhadap peserta didiknya, Ia memantau secara teliti keadaan peserta didik satu dengan yang lainnya. Seperti mencakup kesadaran agama berarti bagian agama yang hadir dalam pikiran yang merupakan aspek mental dari aktivitas agama, dan tindakan terhadap agama yang berada dalam aspek mental, pengalaman membawa keyakinan yang dihasilkan oleh tindakan (amaliah). Pada kata lain pendekatan psikologi agama yang digunakan dalam proses mengajar mencakup kesadaran agama peserta didik yang pengaruhnya terlihat pada mental, gangguan jiwa, dan tindakan.

Adapun rumusan masalah dan penelitian terdahulu sebagai berikut. Rumusan masalah, 1) Bagaimana pendekatan psikologi agama pada pembelajaran Akidah Akhlak di MA AL-Mukhlisin Kampao?, 2) Bagaimana faktor pendukung dan penghambat pendekatan psikologi agama pada pembelajaran Akidah Akhlak di MA AL-Mukhlisin Kampao? Sedangkan penelitian terdahulu dengan penelitian ini pertama, dilakukan oleh Ifanah (2016) yang berjudul "Proses Pembelajaran PAI Melalui Pendekatan Psikologi Agama SMPN 1 Purwokerto.” Penelitian ini membahas adanya gangguan jiwa dan tekanan-tekanan batin pada siswa. Penelitian terdahulu yang kedua dilakukan oleh Dina Muhriani (2017) yang berjudul, "Pendekatan Psikologi Agama dalam Membangun Mental Pemuda Makasar dalam Berinteraksi di Depan Umum" Penelitian membahas bagaimana meningkatkan mental pemuda dan pemudi Makasar dalam berinteraksi di tempat umum. Khususnya di acara-acara besar.

\section{Kajian Pustaka}

\section{Psikologi Agama}

Sejarah perkembangan Psikologi Agama secara pasti belum ada keterangan kapan dimulainya kajian secara ilmiah. Namun para ilmuwan sepakat bahwa kajian hubungan agama dengan kejiwaan telah terdapat pembahasan dalam berbagai kitab suci agama-agama. Untuk memastikan kapan psikologi agama itu mulai dipelajari memang agak sulit. Baik dalam kitab suci maupun sejarah-sejarah agama tidak dijumpai penjelasan mengenai hal tersebut. Akantetapi, penjelasan mengenai hubungan anatara kejiwaan dengan agama banyak diungkapkan di berbagai kitab suci. Sebagai contoh orang yang beriman kepada Allah SWT, berbuat baik dan banyak beribadah akan menjadik jiwanya tenang dan tenteram. Begitupun orang yang tidak beriman dan berbuat maksiat, ia akan gundah dan jiwanya seakan sesak serta tidak tenang. Dari sinilah mulanya para ilmuwan mengembangan bahwa Psikologi Agama itu penting untuk setiap umat manusia.

\footnotetext{
${ }^{4}$ Jalaluddin Rakhmat, Psikologi Agama: Sebuah Pengantar (Mizan Pustaka, 2013).
} 
Psikologi agama terdiri dari kata psikologi dan agama. Kata tersebut mempunyai arti yang berbeda. Psikologi diartikan sebagai ilmu mempelajari gejala jiwa manusia yang normal, dewasa, dan beradap. Sedangkan agama memiliki kaitan dengan kehidupan batin manusia. Menurut Harun, agama berasal dari kata Al Din yang artinya undang-undang atau hukum dan religi (mengikat). Kata agama terdiri dari tidak, "gama"; pergi yang berarti tetap di tempat atau diwarisi turun menurun. ${ }^{5}$ Dari definisi tersebut, psikologi agama meneliti dan menelaah kehidupan beragama pada seseorang dan mempelajari berapa besar pengaruh keyakinan agama itu dalam sikap dan tingkah laku, serta keadaaan hidup pada umumnya, selain itu juga mempelajari pertumbuhan dan perkembangan jiwa agama pada seseorang, serta faktor-faktor yang mempengaruhi keyakinannya.

Berkaitan dengan ruang lingkup dari psikologi agama, maka ruang kajiannya adalah mencakup kesadaran agama yang berarti bagian atau segi agama yang hadir dalam pikiran, yang merupakan aspek mental dari aktivitas agama, dan pengalaman agama berarti unsur perasaan dalam kesadaran beragama yakni perasaan yang membawa kepada keyakinan yang dihasilkan oleh tindakan (amaliah) dengan kata lain bahwa psikologi agama mempelajari kesadaran agama pada seseorang yang pengaruhnya terlihat dalam kelakuan dan tindakan agama orang itu dalam hidupnya. Dalam hal ini psikologi agama telah dimanfaatkan berbagai ruang kehidupan, misalnya dalam bidang pendidikan, perusahaan, dan pengobatan. Psikologi Agama memiliki ruang lingkup pembahasannya tersendiri dan dibedakan dari disiplin ilmu yang mempelajari masalah agama lainnya.

Sebagai contoh pentingnya psikologi agama yaitu dalam Perkembangan jiwa keagaamaan pada orang dewasa misalnya sudah sangat diperhatikan secara tegas. Orang dewasa sudah berpikir tentang tanggung jawab sosial moral, ekonomis, keluarga dan keagamaan, pada masa dewasa ini seseorang berusah mencapai suatu cita-cita yang abstrak yang telah ia rencanakan dengan rasional,orang dewasa juga sudah memiliki sifat kepribadian yang stabil antara lain terlihat dari cara bertindak dan bertingkah laku yang agak bersifat tetap (tidak mudah berubah-ubah) dan selalu berulang kembali.

\section{Pendekatan Psikologi Agama}

Eksistensi Pendekatan Psikologi Agama dalam sebuah pembelajaran diistilahkan dengan education (pendidikan) dan jiwa keagamaaan sangat terkait, karena pendidikan tanpa agama ibaratnya bagi manusia akan pincang. Sedang jiwa keagamaan yang tanpa melalui menegemant pendidikan yang baik, maka juga akan percuma. Dengan kata lain, pendidikan dinilai memiliki peran penting dalam upaya menanamkan rasa keagamaan pada seseorang. Hakikat definisi yang sudah diuraikan tersebut memuat beberapa unsur pokok, pertama; psikologi agama menguraikan tentang kajian berkaitan dengan agama, kedua; psikologi agama menguraikan bagian dari perilaku jiwa seseorang yang tidak sekadar menekankan

\footnotetext{
${ }^{5}$ Kartikowati. Psikologi Agama\&Psikologi Islami.(Kencana: Jakarta) Hlm: 25
} 
perilaku jiwa saja, tetapi juga pada jiwa hakikatnya, ketiga; psikologi agama buka memuat tingkah dan tindakan saja, melainnkan memuat nilai-nilai dari tindakan.

Adapun konsep melalui pendekatan pisikologi pada diri seseorang meliputi; Pertama, Pendidikan Keluarga. Pada konteks pendidikan keluarga merupakan sebuah jalinan dengan unsur-unsur kejiwaan sehingga sulit untuk diidentifikasikan secara jelas, karenaa masalah yang menyangkut kejiwaan manusia demikian rumit dan kompleksnya. Namun demikian, melalui fungsi-fungsi jiwa yang masih sangat sederhana tersebut, agama terjalin dan terlibat di dalamnya. Melalui jalinan unsurunsur dan tenaga kejiwaan ini pulalah agama itu bekembang. Namun hal tersebut, tidak lepas dari interaksi pembangunan mental terhadap anak yang ada di lingkungan terdekat, yaitu keluarga. ${ }^{6}$

Kedua. Pendidikan Kelembagaan. Pendidikan agama di lembaga pendidikan bagaimanapun akan memberi pengaruh bagi pembentukan jiwa keagamaan pada anak. Namun demikian, besar kecilnya pengaruh tersebut sangat tergantung pada berbgai faktor yang dapat memotivasi anak untuk memahami nilai-nilai agama. Sebab, pendidikan agama pada hakikatnya merupakan pendidikan nilai. Oleh karena itu, pendidikan agama lebih dititikberatkan pada bagaimana membentuk kebiasaan yang selaras dengan tuntunan agama. Fungsi sekolah dalam kaitannya dengan pembentukan jiwa keagamaan pada anak, antara lain sebagai pelanjut pendidikan agama di lingkungan keluarga atau membentuk jiwa keagamaan pada diri anak yang tidak menerima pendidikan agama dalam keluarga. ${ }^{7}$

Krtiga, Pendidikan Masyarakat. Masyarakat merupakan lapangan pendidikan yang ketiga. Peran psikologi agama dalam lembaga ini adalah memupuk jiwa keagamaan karena masyarakat akan memberi dampak dalam pembentukan pertumbuhan baik fisik maupun psikis. Yang mana pertumbuhan psikis akan berlangsung seumur hidup. Sehingga sangat besar pengaruh masyarakat terhadap pertumbuhan jiwa keagamaan sebagai bagian dari aspek kepribadian yang terintegrasi dalam pertumbuhan psikis. ${ }^{8}$

Keempat, Perkembangan Kesadaran Batin. Perkembangan adalah serangkaian perubahan progresif yang terjadi akibat dari proses kematangan dan pengalaman. Hal tersebut menunjukkan bahwa perkembangan berarti perkembangan secara kualitatif. Yang artinya bukan hanya sekadar perubahan beberapa sentimeter pada tinggi badan seseorang atau peningkatan kemampuan seseorang, melainkan suaatu proses integrasi dari banyak struktur dan fungsi yang kompleks. Dalam rentang kehidupan terdapat beberapa tahap perkembangan ${ }^{9}$.

Konsep anak mengenai ketuhanan pada umumnya berasal dari pengalamannya. Dikala ia berhubungan dengan orang lain, pertanyaan anak

\footnotetext{
${ }^{6}$ Rakhmat, Psikologi Agama: Sebuah Pengantar.

${ }^{7}$ Rakhmat.

${ }^{8}$ Bambang Syamsul Arifin, “Psikologi Agama (Cetakan Ke-2)," Bandung: Pustaka Setia, 2015.

${ }^{9}$ Ali Miftakhu Rosyad and Darmiyati Zuchdi, "Aktualisasi Pendidikan Karakter Berbasis Kultur Sekolah Dalam Pembelajaran IPS Di SMP," Harmoni Sosial: Jurnal Pendidikan IPS, 2018, https://doi.org/10.21831/hsjpi.v5i1.14925.
} 
mengenai (bagaimana) dan (mengapa) biasanya mencerminkan usaha mereka untuk menghubungkan penjelasan religius yang abstrak dengan dunia pengalaman mereka yang bersifat subjektif dan konkret. Kehidupan agama pada anak sebagian besar tumbuh dari sebab ucapan (verbal). Mereka menghafal secara verbal kalimatkalimat keagamaan dan mengerjakan amaliah yang mereka laksanakan berdasarkan pengalaman mereka menurut tuntunan yang diajarkan pada mereka. Shalat dan doa yang menarik bagi mereka adalah yang mengandung gerak dan biasa dilakukan (tidak asing baginya).

Tindak keagamaan yang dilakukan oleh anak pada dasarnya diperoleh dengan meniru. Dalam hal ini orang tua memegang peranan penting. Pendidikan sikap religius anak pada dasarnya tidak berbentuk pengajaran, akan tetapi berupa teladan. Rasa heran dan kagum meru-pakan tanda dan sifat keagamaan pada anak. Berbeda dengan rasa heran pada orang dewasa, rasa heran pada anak belum kritis dan kreatif. Mereka hanya kagum pada keindahan lahiriah saja. Untuk itu perlu diberi pengertian dan penjelasan pada mereka sesuai dengan tingkat perkem-bangan pemikirannya. Dalam hal ini orang tua dan guru agama mempunyai peranan yang sangat penting. ${ }^{10}$

Kelima, Percaya dengan Kesadaran. Semangat keagamaan dimulai dengan melihat kembali tentang masalah-masalah keagamaan yang mereka miliki sejak kecil. Mereka ingin menjalankan agama sebagai suatu lapangan yang baru untuk membuktikan pribadinya, karena ia tidak mau lagi beragama secara ikut-ikutan saja. Hal ini berangkat dari interpretasi personal siswa. Pada konteks ini harus ada proses komunikasi interpersonal terlebih dahulu yang dilakukan oleh seseorang kepada orang lain dengan tujuan tertentu. Sedangkan interpersonal merupakan merupakan proses penyampaian pesan antara dua orang atau kelompok kecil secara langsung baik itu pesan verbal maupun nonverbal, dengan tujuan untuk mencapai kesamaan makna. ${ }^{11}$

\section{Metode Penelitian}

Penelitian pada konsepsinya merupakan cara ilmiah untuk memecahkan masalah-masalah yang ada dan mendapatkan data dengan tujuan tertentu. Data yang diperoleh melalui penelitian ini adalah data empiris (teramati) yang mempunyai kriteria tertentu yaitu valid. Valid menunjukkan derajat ketepatan antara data yang sesungguhnya terjadi pada objek dengan data yang dapat dikumpulkan oleh peneliti. Penelitian ini menggunakan jenis penelitian kualitatif yang pada dasarnya penelitian ini menyajikan data berupa kata dan kalimat yang dianalisis berdasarkan bentuk yang sebenarnya tanpa melepaskan konteks data yang melengkapi serta memberikan pemahaman dan pemaknaan berdasar interpretasi dan persepsi peneliti. ${ }^{12}$

\footnotetext{
${ }^{10}$ Rakhmat, Psikologi Agama: Sebuah Pengantar.

${ }^{11}$ Arifin, "Psikologi Agama (Cetakan Ke-2)."

${ }^{12}$ Sugiyono, Metode Penelitian Pendidikan:(Pendekatan Kuantitatif, Kualitatif Dan R \& D) (Alfabeta, 2008).
} 
Metode kualitatif merupakan metode penelitian yang mengacu pada filsafat post positivisme yang diperankan untuk meneliti pada kondisi objek alamiah, atau sebagai lawan dari eksperimen dimana peneliti sebagai instrumen kunci dalam mengumpulkan data yang dilakukan secara triagulasi atau gabungan. Analisis data bersifat kualitatif dan induktif, sedangkan hasil penelitian kualitatif lebih menekankan pada generalisasi. Data yang terkumpul analisisnya lebih bersifat kualitatif deskriptif. Kualitatif deskiptif merupakan penganalisisan data dengan cara mendeskripsikan serta menggambarkan data yang telah yang ada sebagaimana dimaksud membuat kesimpulan secara umum. ${ }^{13}$

Penganalisaan data ini dilakukan sejak awal penelitian atau sejak awal pengumpulan data dengan cara menabung informasinya, mereduksi, mengelompokkan, dan menginterpretasi data. Data yang disajikan berbentuk deskriptif, karena data yang diperoleh tidak dapat dituangkan dalam bentuk bilangan atau angka statistik. Pendekatan kualitatif dengan metode deskriptif yang digunakan dalam penelitian ini bertujuan mendeskripsikan fenomena kebahasaan apa adanya. Pengambilan data dilakukan secara langsung di lokasi penelitian dengan menggunakan subjek penelitian sebagai sumber data. ${ }^{14}$

Sumber data adalah subjek penelitian dari mana data diperoleh. Dalam penelitian ini, sumber datanya adalah guru, murid, dan proses pembelajaran Akidah Akhlak di MA AL-Mukhlisin Kampao. Sedangkan data yang akan digunakan dalam penelitian ini adalah hasil wawancara dan pengamatan yang di dapat dari sumbersumber yang dituju. Teknik pengumpulan data adalah langkah yang paling utama dalam penelitian, karena tujuan dalam penelitian adalah mendapatkan data dalam penelitian kualitatif, pengumpulan data dilakukan pada kondisi yang alamiah. Sumber data primer, dan pengumpulan data lebih banyak pada observasi. Adapun teknik atau cara pengumpulan data penelitian ini sebagai berikut.

Pertama, teknik pengamatan secara langsung atau dikenal dengan kata observasi. Teknik tersebut merupakan pengumpulan data yang dilakukan dengan sengaja dan sitematis mengenai fenomena sosial dan gejala-gejala fasis untuk dilakukan pencatatan. Hubungannya dengan penelitian ini, peneliti langsung turun ke lapangan menjadi partisipan untuk menemukan dan mendapatkan data yang berkaitan dengan fokus penelitian. Kedua, Teknik Wawancara. Teknik tersebut merupakan suatu teknik dalam mencari informasi pengumpulan data yang digunakan dengan cara menanyakan sesuatu kepada guru tentang interaksi dalam pembelajaran. Pada saat wawancara peneliti melakukan pencarian informasi atas adanya proses belajar mengajar sesuai data yang dibutuhkan. Ketiga, Teknik Dokumentasi. Teknik tersebut, suatu teknik yang menggali informasi dengan cara memotret keadaan, data, dan lain-lainnya sesuai kebutuhan peneliti.

\footnotetext{
${ }^{13}$ Sugiyono.

${ }^{14}$ Suharsimi Arikunto, “Prosedur Penelitian (Edisi Revisi)," Jakarta: Rineka Cipta, 2002.
} 


\section{Hasil Penelitian}

\section{Pendekatan Psikologi Agama Dalam Pembelajaran Akidah Akhlak Di Ma Al- Mukhlisin Kampao}

Konsepsi ruang lingkup semua pendidikan, telah tahu bahwa guru mempunyai tugas bukan hanya mengajar di dalam kelas saja, tetapi guru harus juga menanamkan adanya nilai-nilai karakter yang ditinjau dari aspek psikologinya kepada siswa. Hal tersebut bertujuan agar siswa menjadi seseorang yang berkarakter. Seseorang disebut berkarakter, sudah jelas seoseorang tersebut mempunyai watak, karatar, dan kejiwaan yang baik. Namun dalam hal ini, seorang guru pada pelaksanaan pendekatan psikologi dalam proses pembelajaran hal pertama yang dilakukan adalah pembentukan karakter yang ditinjau dari pisikisnya. Karena pembentukan karakter yang ditinjau dari psikisnya akan mempermudah adanya proses pembelajaran yang efektif.

Guru harus juga harus mempunyai cara khusus dan strategi agar dapat menanamkan nilai-nilai karakter yang dapat diterima, dipahami, dan diterapkan dalam kehidupan siwa sehari-hari. Jika dalam pembentukan karakter siswa tersebut dilaksanakan dengan baik oleh guru, maka siswa akan mempunyai karakter yang baik. Hal tersebut seperti apa yang dilakukan guru Akidah Akhlak di MA AlMukhlisin ini, dalam membentuk karakter kepada siswa di sekolah yang ditinjau dari aspek psikologinya. Seperti halnya hasil wawancara dengan Bapak Asmui selaku guru Akidah Akhlak; "Membentuk kepribadian dan karakter siswa itu tidak mudah. Setiap siswa itu tidak sama. Guru itu harus cerdik memberi pemahaman dan arahan pada anak. Konsep saya, pertama itu yang ditekanakankan bagaimana cara menyampaikan materi pelajaran dan juga metode pembelajaran yang digunakannya. Saya seringkali melakukan pendekatan dari segi mentalnya. Rata-rata anak itu banyak mendapatkan tekanan batin. Anak itu takut dimarahi jika menyanggah guru yang tidak dapat dimengerti penjelasannya."15 Atas apa yang disampaikan guru Akidah Akhlak tersebut, menunjukkan bahwa adanya pendekatan Psikologi Agama itu penting dalam membangun mental siswa agar aktif dalam proses pembelajaran.

Berdasarkan hasil observasi dan wawancara yang dilakukan, bagian utama yang dilakukan oleh guru Akidah Akhlak MA Al-Mukhlisin dalam menbentuk karakter siswa melalui proses pem-belajaran dengan dengan merancang khusus atas kenormalan sikologinya, setelah itu lalu materi. Karena bagaimanapun juga, kesehatan batin serta tidak adanya gangguan mental dari siswa yang merupakan komponen utama pada proses pembelajaran. Hal serupa juga disampaikan Fitri siswi kelas 10, "Mata pelajarannya Pak Mui sangat asik. Ia tidak pernah menekan muridmuridnya dengan kasar, Ia begitu lembut dan ramah, sehingga siswa tidak merasa takut untuk berinteraksi dalam peoses pembelajarannya." ${ }^{16}$ Dari apa yang disampaikan ole Fitri tersebut, akan diketahui bahwa dalam proses pembelajarannya ditinjau dari segi psikologinya juga termasuk bagian penting dalam membangun

\footnotetext{
${ }^{15}$ Hasil Wawancara Penulis dengan Siswi yang bernama Fitri kelas 10 di MA Al-Mukhlisin, Kampao, Blega, Bangkalan. 12/09/19. 13.30

${ }^{16}$ Hasil Wawancara Penulis dengan Siswi yang bernama Fitri kelas 10 di MA Al-Mukhlisin, Kampao, Blaga, Bangklan. 12/09/19. 13.40
} 
mental yang membentuk adanya karakter yang baik, karena sudah terbukti peserta didik tertarik pada sikap dan pendekatan secara ramah oleh Bapak Asmui tidak mengganggu adanya mental seorang siswa. Oleh karena itu pendekatan dan teknikteknik yang ada dalam pendekatan psikologi ini sangat penting untuk mengetahui kemampuan siswa. Sebab, kadang siswa pintar dan cerdas tidak diketahui oleh guru, karena siswa itu takut untuk menunjukkan kemampuannya. Begitu pula siswa yang tidak cerdas dan tidak pintar, akan kelihatan pintar karena mempunyai mental yang tinggi.

Selain membuat perencanaan pembelajaran dan mengembangkan materi dalam pembelajaran, langkah-langkah pembentukan karakter juga melakukan pendekatan ke siswa dengan meninjau dari aspek psikologi agamanya seperti apa yang disampaikan Bapak Asmui selaku guru Akidah Akhlak berikut; "Kebiasaan bagian dari proses pembelajaran di dalam pendidikan. Pendidikan yang sering dilakukan akan menjadikan kebiasaan yang positif jika pembelajarannya sesuatu yang baik. Hal tersebut jika sering dilakukan, maka akan menjadi tradisi yang luar biasa untuk mengajak siswa berani aktif berbicara dan menyanggah pembelajaran yang ada dan menjadi nilai-nilai untuk membangkitkan mental siswa. Seperti menyucikan diri dengan mengmbil wudu sebelum proses pembelajaran dimulai."17 Seperti apa yang sudah diuraikan sebelumnya, untuk mendapatkan membiasaan prilaku, perlu sedikit dipaksakan walaupun dengan cara halus. Selanjutnya jika sudah menjadi kebiasaan maka akan menciptakan siswa-siswa yang hebat.

Ada beberapa hal terkait adanya tinjauan dari psikologi agama yaitu dari pendidikan keluarga. Seperti apa yang dikatakan oleh Bapak Asmui berikut; "Yang paling utama yang diperoleh siswa dan siswi itu juga berangkat dari keluarga. Sebab, kalau di luar sekolah itu sudah tanggung jawab keluarganya. Tidak mungkin guru memantau ke rumahnya. Namun terkadang, siswa mendapatkan tekanan-tekanan batin dari orang tuanya sehingga sampai dalam proses pembelajaran di sekolah, siswa mendapatkan gangguan untuk memahami pelajaran.." Dari pernyataan di atas menunjukkan bahwa adanya proses pembentukan tingkah laku dan proses penerimaan materi pelajaran, keluarga juga mempunyai peran dalam memberi perhatian pada pendidikan anak dan mendukung serta membuat anak menjadi hebat. Dipandang dari sudut pendidikan, orang tua harus menyediakan situasi dan tempat belajar bagi anak. Dalam ikatan kekeluargaan, orang tua harus mampu menciptakan suasana seperti persahabatan, cinta kasih, kerja sama, disiplin, agar mendapatkan suasana yang harmonis.

Atas uraian pembuktian adanya muatan psikologi agama dari keluarga itu penting, juga disampaikan oleh Lilis Siswi kelas 11 yang menyatakan,"Tekanan orang tua itu sangat berpengaruh, Pak. Sebab, orang tua itu orang yang mempunyai peran utama dalam pendidikan, bukan guru. Sebab, saya semenjak lahir saya mendapatkan pendidikan pertamakali dari orang tua. Bahkan saya selalu mendapatkan dorong-

\footnotetext{
${ }^{17}$ Hasil Wawancara Penulis dengan Guru Akidah Akhlak Bapak Asmui pada di MA Al-Mukhlisin, Kampao, Blega, Bangklan. 16/09/19 14.20

${ }^{18}$ Hasil Wawancara Penulis dengan Guru Akidah Akhlak Bapak Asmui pada di MA Al-Mukhlisin, Kampao, Blega, Bangklan. 16/09/19. 14.30
} 
dorongan untuk menguatkan nilai-nilai agama dengan mental saya agar pikiran dan hati saya tenang dalam mencari ilmu." ${ }^{19}$ Atas uraian tersebut, menunjukkan bahwa didikan keluarga sebagai bentuk psikologi agama yang diberikan kepada anaknya agar terhindar dari gangguan-gangguan mental yang ada.

Selanjutnya pendidikan dari kelembagaan. Pada konteksnya kelembagaan harus membuat konsep-konsep pendukung untuk membangun mental siswa agar bisa membangkitkan sikap kreatif siswa. Seperti halnya apa yang disampaikan oleh Bapak Asmui berikut;" Seperti biasa kegiatan kelembagaan di sini sebelum masuk kelas semua siswa diajak membaca doa bersama agara mendapatkan ilmu yang barokah dan bermanfaat. Tujuan membaca doa bersama sebelum masuk kelas di lembaga ini, agar hati siswa tersebut tenang dan mudah memahami pelajaran." ${ }^{20}$ Atas apa yang disampaikan oleh Bapak Asmui tersebut menunjukkan adanya interaksi pendekatan Psikologi Agama dalam nilai-nilai aktivitas keagamaan.

Pada konteksnya hasil penelitian dalam pendekatan Psikologi Agama juga bisa didukung dengan Kesadaran Batin siswa. Seperti apa yang dikatakan Bapak Asmui beraikut. "Namun semua itu hanya usaha kami sebagai guru untuk menenangkan kejiawaan yang berada di dalam diri siswa. Selanjutnya kami kembalikan lagi pada pada kesadaran siswa. Sebab jaka kesadaran siswa ada, maka meraka akan mendahului kita dalam cara berpikir kritisnya." ${ }^{21}$ Atas apa yang disampaikan pak Asmui tersebut, juga berkaitan dengan apa yang disampaikan Airifin dalam teorinya. Di dalam buku Arifin menyampaikan; kesadaran diri adanya perubahan yang terjadi atas adanya pengalaman dan proses. Hal tersebut menunjukkan adanya perkembangan kualitatif, yang artinya bukan hanya sekadar perubahan bentuk badan, melainkan suatu proses kesadaran batin yang berada pada tubuh manusia.

Seperti apa yang sudah disampaikan konsep teori di atas, bahwa dalam menguatkan proses lancarnya pembelajaran, guru diharuskan memiliki strategi dan teknik secara khusus supaya penanaman dalam nilai karakter dapat dicerna dan diterima siswa, serta dapat dipahami dan diterapkan dalam aktivitas sehari-hari. Jika dalam pembentukan karakter beserta mental ditinjau dari sikologinya dapat dilaksanakan dengan baik, maka secara otomatis akan menghasilkan siswa yang berkarakter baik serta bermental baik pula ${ }^{22}$. Berdasarkan hasil observasi dan wawancara yang dilakukan, kegiatan utama yang dilakukan guru Akidah Akhlak di MA Al-Mukhlisin yaitu Bapak Asmui dalam pembentukan karakter siswa dengan

\footnotetext{
${ }^{19}$ Hasil Wawancara Penulis dengan Siswi yang bernama Lilis kelas 11 di MA Al-Mukhlisin, Kampao, Blega, Bangkalan. 12/09/19. 15.30

${ }^{20}$ Hasil Wawancara Penulis dengan Guru Akidah Akhlak Bapak Asmui pada di MA Al-Mukhlisin, Kampao, Blega, Bangklan. 16/09/19 14.30

${ }^{21}{ }^{21}$ Hasil Wawancara Penulis dengan Guru Akidah Akhlak Bapak Asmui pada di MA Al-Mukhlisin, Kampao, Blega, Bangklan. 16/09/19. 15.00

${ }^{22}$ Implementasi Pendidikan, Karakter Dalam, and Ali Miftakhu Rosyad, "Al-Afkar, Journal for Islamic Studies Ali Miftakhu Rosyad IMPLEMENTASI PENDIDIKAN KARAKTER DALAM PEMBELAJARAN PENDIDIKAN AGAMA ISLAM DI SEKOLAH MUHAMMADIYAH DI KABUPATEN INDRAMAYU Al-Afkar, Journal for Islamic Studies THE IMPLEMENTATION OF CHARACTER EDUCATION THROUGH LEARNING OF ISLAMIC STUDIES IN MUHAMMADIYAH SCHOOL IN INDRAMAYU DISTRICT" 4, no. 1 (2019), https://doi.org/10.5281/zenodo.3321357.
} 
merancang atau mendesain khusus pada kenormalan sikologisnya. Selanjutnya dari hasil wawancara dengan siswa, maka dapat diketahui bahwa pembelajara yang ditinjau dari segi psikologinya, akan membangun mental yang baik, serta akan mendapatkan ketenangan jiwa.

Sedangkan dalam konsep teori juga menjelaskan, pertama; bahwa psikologi agama bagian dari kajian masalah kejiwaan beragama yang membentuk karakter dan mental, kedua; psikologi agama mengkaji aspek perilaku jiwa manusia tidak hanya menekankan perilaku jiwa saja, tetapi juga hakikat jiwa yang sesungguhnya, ketiga; psikologi agama bukan hanya dipandang sebagai sudut pandang etika, melainkan juga dasar jiwa etika ${ }^{23}$. Hal tersebut menunjukkan adanya efisiensi tindakan yang menyatu antara tubuh, gerak, pikiran, dan hati, sehingga semuanya bisa berjalan dengan seimbang.

Beragama dalam konsepsi kesadaran merupakan bagian mental dan aktivitas agama. hal ini merupakan bagian dari agama yang hadir dalam pikiran dan dapat diuji melalui evaluasi diri. Sedangkan maksud dari pengalaman agama merupakan bagian dari unsur pesara dalam kesadaran beragama yang dibawa pada keyakinan yang dihasilkan dari tindakan nyata. Seperti apa yang diuangkapkan oleh siswa dan guru yang berada di MA Al-Mukhlisin Kempao, menjadi sebagai objek penelitian psikologi agama yang ditinjau dari aspek-aspek yang dipelajari sebagai proses untuk mendorong seseorang dalam bersikap dan bertingkah sesuai dengan aturan dari keyakinan yang dianutnya. Secara individu, kesadaran beragama maupun pengalaman agama bisa mempengaruhi orang dalam kehidupannya (peserta didik). Sedangkan hasil penelitian seperti yang sudah dijelaskan, bahwa pembiasaan berawal dari aktivitas yang sering dilakukan.

Konsepsi semangat dalam beragama, bisa dilihat kembali dari masalah keagamaan yang dimiliki sejak kecil. Seseorang ingin menjalankan tugas-tugas keagamaan sebagai lapangan pembuktian atas kepribadiannya. Hubungannya dengan jiwa keagamaan, barangkali dampak globalisasi dapat dilihat melalui hubungan dengan adanya perubahan sikap dan mental. Dari hasil wawancara, adanya perubahan dari sikap dan mental bisa terjadi jika persamaan pendapat pada diri siswa atas sesuatu yang bisa dikendalikan. Hal ini menunjukkan bahwa adanya pengaruh kejiwaan dan kesadaran dinilai dengan baik. Suasana seperti itu, akan terjadi beberapa kemungkinan di antaranya; pertama, tidak terlalu larut pada rekayasa teknologi dan berpegang teguh pada nilai agama sebagai tinjauan dari psikologi, kedua, nilai ajaran agama akan mengalami peningkatan sehingga akan mudah memilih cara untuk menenteramkan jiwanya.

\footnotetext{
${ }^{23}$ M A Zaenudin, "THINKING OF PROSPERITY AND MORAL IN FIQH; Reread of the Book of Bidâyatul Mujtahid Wa Nihâyatul Muqtashid by Ibnu Rusyd (PEMIKIRAN FIKIH KEMASLAHATAN DAN FIQIH AKHLAK; Membaca Kembali Kitab Bidâyatul Mujtahid Wa Nihâyatul Muqtashid Adalah Karya Ibn Rusyd)," Al-Afkar, Journal For Islamic Studies 4, no. 1 (2019): 197-205.
} 


\section{Simpulan}

Dari Hasil Penelitian yang telah dilakukan oleh peneliti mengenai pendekatan Psikologi agama dalam pembelajaran Akidah Akhlak di MA Al-Mukhlisin Kampao, maka peneliti mengambil kesimpulan, pertama, pendekatan psikologi agama pada pembelajaran tersebut, pembentukan karakter dan mental siswa dalam proses pembelajaran yang ditinjau dari psikologi agamanya sangat membantu dan membangun mental yang berlandaskan ketenangan jiwa. Kegiatan tersebut dilakukan oleh guru Akidah Akhlak yaitu Bapak Asmui dengan tujuan agar materi pembelajaran dapat tersampaikan dengan baik kepada siswa. Kedua, faktor pendukung pelaksanaan pendekatan Psikoilogi Agama Pada Pembelajaran tersebut sebagai berikut, a) guru dapat lebih variatif dalam menggunakan media pembelajaran sehingga lebih efektif dan efisien, b) budaya sekolah identik dengan keberadaannya yang berada di bawah naungan Yayasaan Durrotun Nasiin yang berkonsep interaksi saling mempengaruhi antar individu di dalamnya yang disebabkan kekentelan berkaitan dengan agama islam. Sedangkan Faktor Penghambat Pelaksanaan Pendekatan psikologi agama pada pembelajaran tersebut adanya perbedaan Individu yang masing-masing siswa mempunyai karakteristik yang berbeda-beda, baik dilihat dari segi fisik maupun psikis. Dengan adanya perbedaan ini menuntut adanya perbedaan perlakuan antara siswa yang satu dengan yang lain. 


\section{DAFTAR PUSTAKA}

Nurhadi, Ali. 2019. Penerapan Komunikasi Interpersonal Tenaga Pendidik dalam Pencapaian Prestasi Belajar Siswa di MTs Nahdliyatul Islamiyah Blumbungan Larangan Pamekasan. Jurnal Alfikrah. Bangkalan: Sekolah Tinggi Agama Islam Al-Hamidiyah.

Asmui. 2019. Guru Akidah Akhlak. MA Al-Mukhlisin, Kampao, Blega, Bangkalan.

Fitri. 2019. Siswi kelas 10. MA Al-Mukhlisin, Kampao, Blega, Bangkalan.

Ifanah, 2014. Proses Pembelajaran PAI Melalui Pendekatan Psikologi Agama SMPN 1 Purwokerto. Universitas Muhammadiyah Purwokerto: Purwokerto

Kartikowati. 2016. Psikologi AgamaEPsikologi Islami. Jakarta: Kencana Lilis. 2019. Siswi kelas 11. MA Al-Mukhlisin, Kampao, Blega, Bangkalan.

Muhriani, 2017. Pendekatan Psikologi Agama dalam Membangun Mental Pemuda Makasar dalam Berinteraksi di Depan Umum. Universitas Makasar: Makasar

Arifin, Bambang Syamsul. "Psikologi Agama (Cetakan Ke-2)." Bandung: Pustaka Setia, 2015.

Arikunto, Suharsimi. "Prosedur Penelitian (Edisi Revisi)." Jakarta: Rineka Cipta, 2002.

Ali Miftakhu Rosyad. “Al-Afkar, Journal for Islamic Studies Ali Miftakhu Rosyad IMPLEMENTASI PENDIDIKAN KARAKTER DALAM PEMBELAJARAN PENDIDIKAN AGAMA ISLAM DI SEKOLAH MUHAMMADIYAH DI KABUPATEN INDRAMAYU Al-Afkar, Journal for Islamic Studies THE IMPLEMENTATION OF CHARACTER EDUCATION THROUGH LEARNING OF ISLAMIC STUDIES IN MUHAMMADIYAH SCHOOL IN INDRAMAYU DISTRICT" 4, no. 1 (2019). https://doi.org/10.5281/zenodo.3321357.

Rakhmat, Jalaluddin. Psikologi Agama: Sebuah Pengantar. Mizan Pustaka, 2013.

Rosyad, Ali Miftakhu. "THE ACTUALIZATION OF MULTICULTULARISM VALUES THROUGH SOCIAL STUDIES LEARNING AT STATE JUNIOR HIGH SCHOOL 2 JUNTINYUAT IN REGENCY INDRAMAYU BACKGROUND OF THE PROBLEM," n.d.

Rosyad, Ali Miftakhu, and Darmiyati Zuchdi. "Aktualisasi Pendidikan Karakter Berbasis Kultur Sekolah Dalam Pembelajaran IPS Di SMP.” Harmoni Sosial: Jurnal Pendidikan IPS, 2018. https://doi.org/10.21831/hsjpi.v5i1.14925.

Sugiyono. Metode Penelitian Pendidikan:(Pendekatan Kuantitatif, Kualitatif Dan $R \mathcal{E}$ D). Alfabeta, 2008.

Suyanto, Slamet. “Dasar-Dasar Pendidikan Anak Usia Dini.” Yogyakarta: Hikayat Publishing, 2005.

Zaenudin, M A. "THINKING OF PROSPERITY AND MORAL IN FIQH; Reread of the Book of Bidâyatul Mujtahid Wa Nihâyatul Muqtashid by Ibnu Rusyd (PEMIKIRAN FIKIH KEMASLAHATAN DAN FIQIH AKHLAK; Membaca Kembali Kitab Bidâyatul Mujtahid Wa Nihâyatul Muqtashid Adalah Karya Ibn Rusyd)." Al-Afkar, Journal For Islamic Studies 4, no. 1 (2019): 197-205. 